\title{
Factors contributing to course changes among students at welwitchia university in Namibia: a student nurse perspective
}

\author{
Esther Kamenye $^{1 *}$, Scholastika lipinge ${ }^{2}$, Denise Du Plessis ${ }^{3}$ \\ ${ }^{1}$ Community Health Department, Clara Barton School of Nursing, Welwitchia University (WU), Windhoek, Namibia \\ ${ }^{2}$ Clara Barton School of Nursing, Welwitchia University(WU), Windhoek, Namibia \\ ${ }^{3}$ Department of General Nursing Science, Clara Barton School of Nursing, Welwitchia University (WU), Windhoek, Namibia \\ *Corresponding author E-mail: kamenyene@gmail.com
}

\begin{abstract}
The overarching purpose of this study was to explore and describe the factors contributing to the changing of study courses among student nurses at Welwitchia University in Namibia. A qualitative explorative, descriptive and contextual research design was conducted, using individual in-depth interviews to gather information from 55 students, registered at Welwitchia University from 2013 to 2015 , who had changed their course of study before joining the university. A purposeful sampling (convenience) technique was used. Interviews were conducted from October to November 2015 until the data were saturated.

The results of this study established that after completing Grade 12, students enrol for any courses with no clear sense of understanding of the choice they have made just to keep themselves busy. This is mostly done when they have been rejected for their initial choice of course (nursing course) at the universities to which they have applied. The study also revealed that some students enrol for courses that are chosen for them by their families, which results in students later changing courses to one of their preference that is nursing. Others changed courses to nursing because they found the first course too difficult.

The recommendations based on the findings of this study include the consideration of a gap year to take up voluntary jobs at places like old age homes, orphanage homes to practice caring activities while waiting to be admitted for the nursing course, and introducing or strengthening of career guidance at all secondary schools and institutions of higher learning.
\end{abstract}

Keywords: Course; Career Guidance; Student; Change.

\section{Introduction}

Making decisions about a field of study while still at secondary school can be problematic, because it has implications for a student's future career as well as their future level of income and standard of living. Moreover, having to decide on a different course of study at a later date adds to the stress already experienced. Farlex (2003-2015) defines a career as a profession chosen as one's life's work. A career is described as a profession that usually involves formal training or a formal education and that is considered to be a person's lifework. In some careers, employees stay in one job for their entire career, while in others there is an increasing trend of employees changing jobs more frequently.

According to Academy One, Inc, (2016), changing course or field of study is one of the things students often consider after enrolling at an institution of higher learning. Many students change their field of study and this result in them taking longer to complete their college/university education (Academy One, Inc, 2016). Consequently, many end up spending a lot of money before they graduate and some even give up their studies altogether, not seeing how it relates to their present circumstances and only experiencing the consequences years later [Moldoff, 2006-2015].

Moldoff (2006-2015) explains that, when considering whether to change courses, students should think about the following: if a student has only a semester or one or two years of study left, what would be the implications of finishing what he or she has started?
Firstly, finishing one's studies demonstrates that a student has what it takes to complete the task. Secondly, finishing demonstrates that a student can overcome distractions, self-interest and unforeseen challenges. Finishing what a student starts, even if he or she doesn't like it, has a positive outcome on the student's future. When it comes to applying for jobs, it demonstrates to prospective employers that the applicant is self-confident, reliable and consistent and is able to finish difficult tasks - this is one of the key attributes that differentiate people from one another.

Based on Academy One, Inc (2016)'s statement, field of study often shows a weak correlation with what people end up doing in many jobs. Generally, professional and technical careers in the health care field do correlate with the field of study, but in many careers such correlations are fewer. For instance, many people who study music and art end up working in business settings and some go into computer programming. The field of study or course is then just a form of specialisation which demonstrates that a person can concentrate on their studies and succeed. It does not lock a person into a job for life (Moldoff, 2006-2015). Nevertheless, instances of students changing their course of study before completion of the initial course are on the rise.

According to Ramos (2015), some students start college with a career that their parents or relatives have chosen for them or have advised them to take up, not realising that if they end up changing majors, particularly at a later stage of their studies, it will take them longer to graduate. In many cases these students struggle to 
make a final decision because they do not know how to confront their loved ones about a career change (Ramos, 2015).

Furthermore, Ramos (2015) states that according to the National Center for Education Statistics, about 80 per cent of students in the United States end up changing their major course at least once. On average, college students change their field of study at least three times over the course of their college career. A change of a course of study can occur within departments, or within the same college, from mechanical to civil engineering for example, and sometimes across colleges faculties, for example from education to health sciences.

According to Simonnov (2012), some students go to college knowing exactly what they want to do, but most don't. At Penn State University, 80 per cent of freshmen, even those who have declared their major courses, say they are still uncertain about their courses, and half will change their minds afterwards, sometimes more than once.

Drew (2011) states that roughly 40 per cent of students from the University of California in Los Angeles studying in the engineering and science fields end up switching to other subjects or failing to get a degree altogether. This figure increases to as much as 60 per cent when pre-medical students, who typically have high school science preparation, are included in the data (Drew, 2011). According to Claeys-Jackson (2015) all students may at some point question their choices, experience thoughts of dropping out of university or changing their course of study; generally this affects first years in particular. Some of the causes of such doubts may be the fact that the university is not right for the student or that students choose a course that is too difficult. This may be the result of the growing number of possibilities that are open to students (Simonnov, 2012).

\subsection{Problem statement}

According to the 2013-2015 student academic records of the Welwitchia University (WU) in Namibia, 101 out of 239 students had initially enrolled for other fields or courses of study at other international or local universities before enrolling for the nursing course at WU. Some students had even changed their field of study more than twice before register themselves at Welwitchia University (Welwitchia University, 2013-2015). During the research discussed here, the researchers questioned this pattern, attempting to ascertain whether the students were aware that changing courses would delay their graduation, delay their employment and prolong their dependence on their parents or guardians' support.

Apart from delaying their graduation and subsequent employment, the students might also waste their parents, guardian's or sponsor's money.

It would seem that students did not receive career guidance while at secondary school, or it might have been that they were forced to follow a career they were really not interested in. On the other hand, they may also have been influenced by friends to change course.

Accordingly, the following research question was identified: What are the factors contributing to the course changes among student nurses at Welwitchia University? The researchers are not aware of any study that has been conducted in Namibia on this topic (exploring the factors that are contributing to the course change among student nurses).

\subsection{Aim of the study}

The purpose of the study was to explore and describe the factors contributing to changing the course of study (from other field of study to nursing) among students studying nursing course at Welwitchia University in Namibia.

\subsection{Research objectives}

The following objectives were identified for the study:

- To explore the reasons for changing courses/field of study among students at WU

- To ascertain whether students had been exposed to career guidance/services while attending secondary school

- To determine the impact that a change in course of study has on the students' families or sponsors

- To explore whether a change of course contributes to a negative attitude in students towards their current study.

\subsection{Significance of the study}

This study could provide helpful data that might lead to the introduction or strengthening of career guidance in all secondary schools, universities and colleges in Namibia. The results of this study may provide reliable data on why students keep changing courses/field of studies, which could help the researchers to make recommendations on when and how career guidance should be provided in secondary schools, universities and colleges in Namibia. It may also assist students to make the right choice before wasting their time and their parents', guardian's, government's or sponsor's money. It will also assist the government and other sponsors to invest money wisely in the right students who are following the right career at the right time.

\section{Study design and methods}

This study was a qualitative in its approach and has followed an explorative, descriptive, and contextual design. The population for this study was all student nurses who had changed their courses of study before joining nursing course at Welwitchia University. According to the academic records of WU (2013-2015), 101 students out of 239 students registered from 2013 to 2015, had changed their course of study before they joined nursing course at Welwitchia University. In this study, the sample comprised all student nurses at Welwitchia University who had changed their field of study before registering at WU as student nurses. A purposeful sampling (convenience) technique was employed and the data were collected by the researchers through in-depth individual interviews structured in accordance with an interview guide until the data were saturated. In this study 55 student nurses were interviewed whereby fourty nine (49) were female and six (6) were male. As one can expect most of the respondents are females while the rest are men. This is just confirming the perceptions that nursing is a female profession in general.

\subsection{Research setting}

The study was conducted at Welwitchia University, a private institution of higher education in Namibia, from October to November 2015. Welwitchia University is only offering a bachelor degree in Nursing Science.

\subsection{Inclusion and exclusion criteria}

\subsubsection{Inclusion criteria}

For this study, the students had to:

- Have been registered at WU between 2013 and 2015

- Be currently studying at WU

- Have changed their course of study before joining nursing course at WU

- Give voluntary verbal consent to participate.

\subsubsection{Exclusion criteria}

The following students were excluded from the study:

- Students who had not changed their course of study since Grade 12 , but had taken a gap year 
- Students who had studied at an institution of higher learning with the aim of improving their Grade 12 points

- Students who were unwilling to participate in the study.

\subsection{Pilot study}

Nieswadomy (2002) refers to piloting as a primary prevention. In this research, a pilot study was carried out with the main aim of pretesting the data collection instrument before the researchers conduct the main study. The pilot study was conducted at Welwitchia University using a purposeful convenience sampling method to identify three students who had also changed their course of study before joining WU during 2013 to 2015. The students who participated in the pilot study did not participate in the main study. Following the pilot study, very few adjustments were subsequently made to the interview guide.

\subsection{Trustworthiness of the study}

The trustworthiness of the entire study was assessed using the criteria proposed by Lincoln and Guba, namely, the credibility, transferability, dependability and confirmability of the study (as cited in Polit \& Beck, 2012, p. 172).

\subsection{Data analysis}

The rationale for data analysis is to organise, impose structure on and elicit meaning from data (Polit \& Beck, 2012). In this study, content analysis was used to analyse the data since it is the most reliable method used in qualitative research, quite systematic and allows the researcher to organise the information into themes and sub-themes (Leedy \& Ormrod 2010; Steve, 2001). Accordingly, the researchers read through the transcripts, starting with shortest transcript, and identified themes that were repeated over and over by the respondents. Thereafter, the themes were grouped to form categories, based on the similarities that emerged from the data.

\subsection{Ethical considerations}

Participation in this research was voluntary and informed consent to participate was obtained from the participants themselves. All the participants who were approached were willing to participate in the study, and all of them gave their informed verbal consent before taking part in the study. The confidentiality of the information was safeguarded and the privacy of all participants was respected. This was done by not using the names of the participants and the data were reported using aggregates rather than individual identities. Participants were assured that their names would not be disclosed, with the findings being reported in group form. In addition, the research proposal was submitted to WU Research Committee for approval purposes prior to the start. After careful consideration of the research proposal, approval was granted.

\section{Results and discussions}

\subsection{Themes and sub-themes}

In this study, following the data analysis process, four themes and subthemes emerged. Each theme is discussed here and is accompanied by relevant quotes of the students. Pertinent literature is also cited as a literature control to the findings of the study.

The main aim of using the literature control was to compare the findings of this study with the findings of other studies around the world; thus identifying any similarities, differences and unique contributions. This also enhanced the trustworthiness of this study. The following table gives the themes and sub-themes for this study.

Four themes were identified in this study and are given here together with the sub-themes.
Table 1: Themes and Sub-Themes

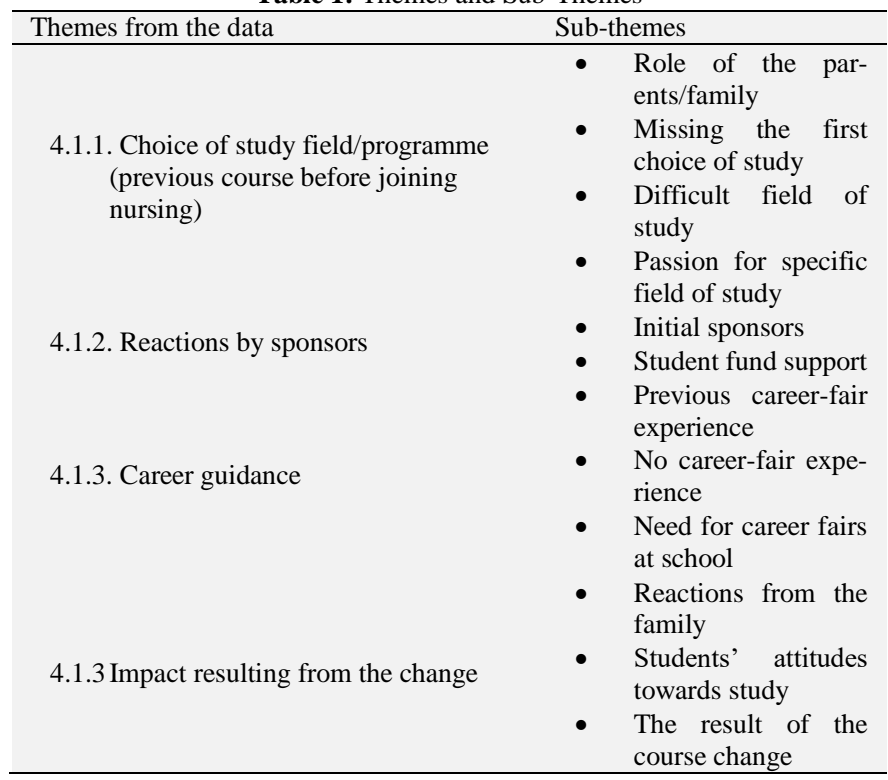

\subsubsection{Choice of study field/programme (previous course before} joining nursing)

- Role of the parents/family in choosing of the field of study

This study revealed that for some students their previous course of study was chosen for them by their parents to keep them busy, especially when they did not get into the course of their choice. It was also revealed that some students were forced by their parents to do courses which they themselves did not really want to do.

"My parent chose that course (millwright) for me. I wanted to study something professional like nursing" (23 years old, thirdyear student).

"My mother is the one chose that course for me (receptionist). She is also a receptionist, but me I like nursing; therefore I changed to do nursing" (29 years old, second-year student).

"My parents forced me to do that course (economics). I really do not like that course. I like nursing" (25 years old, second-year student).

A few indicated that they had been forced by their extended families to take the courses, which they didn't even like.

"My aunt is the one who chose that course for me (Travel and tourism). Myself I do not like the course. I like nursing" (22 years old, second-year student).

"My brother chose that course for me to be an accountant like him, but I like nursing" (25 years old, third-year student).

"My sister is the one chose that course (finance management) for me and even registered me for that course. I changed because I like nursing" (21 years old, second-year student).

A study conducted by Shahzad, Zahra and Ahmed (2014) among students at the University of Gujrat Hafiz Campus, the Fatima Jinnah College, the Marghzar College and the Zamindar College examined the effects on career selection. Almost all the students expressed the perception that people other than the students themselves, for example parents, were most influential in the selection of a career. By contrast, in this study most of the students preferred to choose their field of study for themselves and did not consider family influence to be a factor.

Fisher (2007) emphasises the importance of parental involvement, indicating that without parents' "motivation, many students will enter university/college without direction and simply go through the motions; financial resources will be wasted and parents will become frustrated; students will feel increased anxiety as the need to find a job approaches and others will graduate with degrees that the student has no desire to use in the market".

Another reason for changing courses may be selecting a major for the wrong reason. If a student feels pressured by family members to choose a certain major or follows the example of a friend or a 
significant other in their choice of major, second-guessing their decision is natural. Ultimately, it's the student's life and career path, and it's hard to succeed if they have chosen a career for the wrong reason.

Uninterested in courses: If, after taking a few of the required courses for a specific major, the student is still not interested in the topics, it may be time to switch gears. While not every required course is going to be one's favourite, the concepts should be something that the student is inherently excited to learn more about (Cengage Learning and Cengage Brain, 2013).

- Missing the first choice of study

Many of the respondents/students indicated that they had chosen the course of study themselves, not because they liked the course but merely in order to keep themselves busy because they had been rejected when applying for nursing. Ultimately, they changed their course of study and enrolled for a nursing course at WU when they were accepted.

"I was not accepted to the course I wanted (nursing at University of Namibia) therefore I just take Bachelor of Business Management to keep myself busy" (23 years old, second-year student).

"I chose the course myself (pilot) just to keep myself busy, because there were no other ways. I wanted to do nursing" (20 years old first-year student).

"I just took the course during the selection time (taxation management), because there were no other ways" ( 23 year old thirdyear student).

The findings concur with those of a study conducted among the students at the University at Prince of Songkla University, Pattani campus in Southern Thailand that revealed that one of the reasons why students discontinuing the their study is when students enrolled in a non - preferred field of study (Sittichai, 2012).

A few indicated that they had registered for no valid reason:

"I was looking for school and I found people registering at the local Namibia University of Science and Technology (NUST), I just joined them and register myself also with no valid reason. I wanted to be a nurse, but I have no science subjects" (34 years old second-year student)

"I just took the course (bachelor of public management at University of Namibia) with no good reasons. I just took it as long I am studying. Now I changed, because I feel that I love nursing" (30 years old second-year student).

This implies that some students, when they were not accepted into their field of choice they registered for any available course to keep them busy with studies even though they did not like them. This usually results in a waste of resources; on the other hand, however, the student might get to like it in the process (Cengage Learning and Cengage Brain, 2013).

- Difficult field of study

A few respondents indicated that they changed to nursing because they found the first course of study too difficult.

"The first course (HIV/AIDS Management) was hard to me" (23 years old, third-year student).

"Accounting particularly Auditing was very difficult to me" (25 years old, second-year student).

"That was the only chance I got to do Diploma in Banking and Finance, nothing else, I was not performing well, therefore I changed to nursing" (20 years old, third-year student).

Struggling with courses is another reason that can force a student to change to another course. It is one thing to fall slightly behind on coursework; it is another issue if you are entirely unable to grasp the concepts. If you are putting in your full effort in that course and still aren't able to succeed, it may be time to reconsider your major.

- Passion for specific field of study (nursing)

All students indicated that they had a passion for nursing therefore they were just happy when they were accepted into the nursing course.

"I like nursing and it is what I wanted to do as from my childhood" (34 years old, third-year student).
"I wanted to register for nursing, but I found the course was full at UNAM, then I just register for education, but it was not really what I wanted, therefore I changed to nursing" ( 20 years old, second-year student).

I like nursing, firstly I applied at University of Namibia (UNAM) for nursing but it was full, then I decided to do Pre-Hospital Emergency Medical Care at NUST. I changes again to nursing. Now I am happy (23 years old, second-year student).

Other reasons for changing the course of study

Other students chose the previous courses themselves and changed to nursing for the following reasons:

- Took the previous (non-nursing) course because their Grade 12 points were not sufficient to be admitted to nursing.

- Changed to nursing because nursing is in demand and getting a job would be easy after graduation.

- Failed the previous course, claiming that they did not like the course.

- Experienced financial constraints with regard to studying outside the country.

- Wanted to work only in a hospital setup.

According to Williams (2015), students change majors because they do not like the course or because they subsequently find what they would like to do. It can happen that they are not encouraged to explore, experience a lack of understanding, or the obvious money vs passion. This concurs with the findings of this study. In this study the majority of students changed courses because they found what they most wanted to do. In addition, some were confident that they would be employed easily after graduation because nurses are in demand in Namibia.

\subsubsection{Reactions by sponsors}

\section{- Initial sponsors}

Some students whose fees were paid by their families indicated that their families were happy to continue paying their fees for the nursing course because they wanted them to be nurses initially.

"My mother feels good because she also wanted me to be a nurse because she is also a nurse" (22 years old, second-year student).

"My father said that is fine as long I am studying what I like" (26 years old, second-year student).

Some students indicated that their families were not happy because they had wasted their money and also their time while studying other courses.

"My parents feel bad, because I wasted their money and my time" (34 years old, second-year student).

"My husband was not happy at the beginning, because it was like money wasting" (39 years old, second-year student).

- Government student fund support

Some respondents/students indicated that they had a Namibia Students Financial Assistant Fund (NSFAF) loan and, after informing the NSFAF that they had changed the course, the NSFAF promised to transfer the money but it never happened:

"They promised to transfer the loan, but nothing happen till now" (23 years old third-year student).

For some students loans were cancelled, others were told by the Namibia Students Financial Assistant Fund (NSFAF) to reapply, while a few students' loans were put on hold.

"They cancel the loan, because I quit the previous course (millwright diploma)" (23 years old second-year student).

"NSFAF told me to re-apply" (27 years old, third-year student).

"They put the loan on hold, and will be transferred next year" (22 years old, second-year student).

A few students indicated that the NSFAF did not respond when they informed them about changing:

"I informed them, and I am still waiting for their response" (23 years old, second-year student).

"I informed them few weeks ago. I am still waiting for their response" (21 years old, second-year student). 
A few indicated that their loan has been transferred to their current course. However, others had not yet informed the NSFAF about changing courses.

"My loan has been transferred, but it was a long process" (23 years old, third-year student).

"I did not inform them yet" (25 years old, second-year student).

\subsubsection{Career guidance}

\section{- $\quad$ Previous career fair experiences}

The majority of students indicated that they had the chance to attend a career fair while they were in Grade 12 at places like University of Namibia and Namibia University of Science and Technology.

The majority of students maintained that career guidance helped a great deal in choosing the right career and believed that this should be introduced during Grade 10 or earlier, so that a learner could choose the right subjects early on. Currently, career guidance is done mainly in Grades 11 and 12, which is already very late. Some learners had wanted a career in the science field but had found it impossible because some secondary schools do not offer science subjects. The following responses in this regard are from some of the participants:

"It is better for them to come as earlier as possible (while in Grade 10) so that a person can make a right decision early by choosing the right subjects for grade 11" (23 years old, secondyear student).

"The time they come to our school, it was late already, because at some schools you are just placed at the field with no science subjects. I think it will be better if the career guidance starts at Grade 10 so that learner can make correct choice of the subjects" (34 year old, second-year student).

- No career fair experiences

It would seem that students did not receive career guidance while attending secondary school, or it could be that they were forced to follow a career they really did not want, or that they were influenced by friends to change courses.

Very few had any idea about career guidance, and were not given a chance to attend a career fair while at secondary school.

"I do not have any idea. They never visit our school" (22 years old, second-year student).

This concurs with the results of a study conducted at Ferris State University Career Institute for Education which also revealed that most teenagers are receiving little to no career guidance and they are not pursuing the appropriate educational plan for real-world career opportunities. More than half of the students surveyed $(51 \%)$ could not identify someone in high school who had acted as a mentor in advising them on career or job options (Garder Business Media Inc, 2015).

However, according to Venable (2011) a student can seek career guidance from the career services office at his or her institution or they can search the internet for free. A student can also undergo an aptitude test, or take a free test on careers on the internet

- Need for career fairs at schools

In this study, all the students interviewed indicated that there is a need for career fairs at schools to guide learners early at the junior secondary level. This would help students to take the right subjects and ultimately to choose the correct field of study.

\subsubsection{The impact of changing the course of study}

\section{- Reactions from the family}

Many of the students indicated that changing their course of study did not have any negative effects on either their families or themselves. Their families were very supportive, because the students are currently studying the career their families and the students themselves prefer.

Some indicated that their families had complained that they had wasted time and money; they should have completed the course already and started supporting both themselves and the family.
"My mother used to say that I have wasted their money and time" (22 years old, second-year student).

"My brother is the one who is always complaining, he is the only one who is responsible for my taxi money" (24 years old, secondyear student).

"It have a negative impact on my family because I have a daughter, they have also to look after" (28 years old, second-year student).

- Students' attitudes towards study (nursing science)

Many of the students indicated that they were very positive towards their studies because they were studying the field they liked most.

Certain participants indicated that they had developed some negative thoughts about the study, particularly when the study (nursing) became tougher.

"It disturb me sometimes because I really waste my parents' money" (22 year old, second-year student).

"I develop negative thoughts when I fail the test" (22 years old, first-year student).

- The results of the course change

The students receiving financial assistance from the Government of Namibia tend to struggle to transfer their loan or bursary from one institution to another. Such students may miss lectures particularly during the first semester because they have to run up and down searching for their previous records and declarations. This contributes to higher absenteeism and poor performance and if a student is attending lectures they might not concentrate as a result of financial concerns.

\section{Conclusions}

It became evident from the findings of this study that many students merely registered for a course of study initially to keep them busy, without considering that they were wasting their parents' money and delaying their graduation. Some students registered for no good reason and studied with no particular purpose in mind.

Some parents and families advised and/or forced students to take courses the students did not like; later the student would be forced to quit and take another course he/she liked more. This wastes time and money. Other reasons for changing the course of study revealed by this research included not being accepted into the first choice of study; finding a field of study too difficult; taking the previous (non-nursing) course because their Grade 12 points were insufficient to be accepted for nursing; changing to nursing courses because nursing is in demand and they would get jobs easily after graduation; failing the previous course because they did not like it; financial constraints that prevented them from studying outside the country; and wanting to work in a hospital setup. In conclusion, it also became evident from the findings of this study that some schools do not have career guidance programmes and those that do, start giving career advice to learners very late. Moreover, some schools do not offer science subjects, which are very important for some courses nowadays especially nursing. Recommendations

The following recommendations are made based on the findings of this study:

- Gap year and taking voluntary job: The learner should be informed about the importance of taking a gap year to think critically about their future career and they should also undergo an aptitude test so that they are able to choose the right course first time round. The students who want to join nursing field can do voluntary jobs at places like old age homes and orphan homes to practice caring activities while waiting to be admitted at nursing institutions. The results of this study revealed that some students register at any institution of higher learning just to keep themselves busy, without realising that they are wasting their parents' money.

- Career guidance at secondary schools: The directors, principals and heads of departments at schools in Namibia should arrange earlier for career guidance/fairs, starting when the 
learners are still in Grade 10 or even earlier. This will assist learners to choose subjects in Grade 11 that will suit the career the student will pursue after Grade 12.

- All secondary schools to have all fields of studies: It was evident from this study that some schools do not have science subjects and that this later has a serious effect on the career the student wishes to take especially if the students want to take nursing course.

- Career guidance at all institutes of higher learning: To establish a career guidance department and, in those schools that such a department, to strengthen its functions. This would be mainly to assist students who register and study with no particular field in mind, thus wasting their parents' money. It was evident in this study that some students are studying with no particular objective in mind.

- Freedom: Learners should be given the freedom to choose a career for themselves that they are happy studying towards, rather than studying because they have been forced into a certain course. The results of this study revealed that some students had been forced by parents and extended family members to take certain courses; while others revealed that the course they were studying had been chosen for them.

- Motivation to complete the course they started: The students need to be motivated to complete what they have started.

\section{Limitations of the study}

Although the researchers assumed that the students would respond to questions honestly, students may have answered questions in a manner which they perceived as being more polite. The likelihood of this may have been even greater owing to the fact that the researchers are their lecturers. This was, however, beyond the researchers' control.

\section{Acknowledgements}

We thank all the students who took the time to participate in this study; without their participation this study would not have been a success or even been possible.

\section{Competing interests}

The authors declare that they have no financial or personal relationship(s) which may have inappropriately influenced them in writing this article

\section{References}

[1] Academy One, Inc. (2016). For Students changing majors and exploring college transfer. Retrieved September 06, 2016 from http://www.collegetransfer.net/ContinueMyEducation/ChangeSwitc hTrans-

fer/TransferStudentCenter/ForChangingMajors/tabid/999/default.as px.

[2] Cengage Learning and CengageBrain. (2013). Five (5) reasons students should change their majors. Retrieved March, 12, 2016 from http://www.howtolearn.com/2013/01/5-reasons-students-shouldchange-their-major/.

[3] Claeys-Jackson, D. (2015). Feature: Leaving your course. Retrieved October 18, 2015, from http://www.prospects.ac.uk/features_leaving_your_course.htm.

[4] Drew, C. (2011). Why Science majors change their minds. Retrieved October 19, 2015, from http://www.nytimes.com/2011/11/06/education/edlife/why-sciencemajors-change-their-mind-its-just-so-darn-hard.html?_r=0.

[5] Farlex. (2003-2015). The free dictionary. Retrieved October 20 , 2015 from http://www.thefreedictionary.com/career.

[6] Fisher, B. (2007). Parent involvement in student career planning. Retrieved March, 12, 2016 from
http://ncda.org/aws/NCDA/pt/sd/news_article/5344/_PARENT/lay out_details_cc/false.

[7] Gardner Business Media. (2015). Lack of career guidance among high school students. Retrieved November 07, 2015 from http://www.mmsonline.com/columns/lack-of-career-guidanceamong-high-school-students.

[8] Leedy, P.D., \& Ormrod, J.E. (2010). Practical Research: Planning and Design $\left(9^{\text {th }}\right.$ ed.).New Jersey: Pearson.

[9] Mordoff, D. K. (2006-2015). For students changing majors and exploring college transfer. Retrieved October 19, 2015, from http://www.collegetransfer.net/ContinueMyEducation/ChangeSwitc hTrans-

fer/TransferStudentCenter/ForChangingMajors/tabid/999/default.as px.

[10] Nieswadomy, R.M. (2002). Foundation of Nursing Research (4 $^{\text {th }}$ ed.). New Jersey: Prentice Hall.

[11] Polit, F. D., \& Beck, C. T. (2012). Nursing research: Generating and assessing evidence for nursing practice (9th ed.). China: Lippincott Williams \& Wilkins.

[12] Ramos, Y. (2015). College students tend to change majors when they find the one they really love. Retrieved October 14, 2015, from http://borderzine.com/2013/03/college-students-tend-to-changemajors-when-they-find-the-one-they-really-love/.

[13] Simonnov, S. C. (2012). Guidance counsellor/Field of study/Major decision. Retrieved October 18, 2015, from http://www.nytimes.com/2012/11/04/education/edlife/choosingone-college-major-out-of-hundreds.html?_r=0.

[14] Sittichai, R. (2012). Why are these dropouts among University students: Experiences in a Thailand University? International Journal of Educational Development, 32 (2), 283-289. Retrieved September 08, 2016 from http://www.sciencedirect.com/science/article/pii/507. http://dx.doi.org/10.1016/j.ijedudev.2011.04.010.

[15] Shahzad, N., Zahra, S. T., \& Ahmed, M. A. (2014). Determinants and influences on students career choice. University Journal of Management and Social Science, 4(3), March. Retrieved March, 11, 2014 from http://www.researchgate.net/publication/2718503.

[16] Steve, S. (2001). An Overview of Content Analysis: Practical Assessment, Research and Evaluation. 7 (17). Retrieved September 10, 2016 from http://pareonline.net/getvn.asp?v=7\&n=17.

[17] Venable, M. (2011). What influences your career choice? Retrieved March 11, 2016 from http://www.onlinecollege.org/2011/05/17what-influence-yourcareer.

[18] Welwitchia University. (2013 - 2015). Student Academic Records. Windhoek: Welwitchia University Press.

[19] Williams, S. (2015). Reasons why students change majors. Retrieved November 06, 2015 from http://www.theshorthorn.com/life_and_entertainment/reasons-whystudents-change-their-majors/article_9620078e-1326-11e2-9338001a4bcf6878.html. 